\title{
Point Of Care Testing of Ionized Magnesium in Blood with Potentiometric Sensors - Opportunities and Challenges
}

\author{
Wei Zhang*
}

Siemens Healthcare Diagnostics, Norwood, MA, 02062, USA

*Corresponding author

Wei Zhang, Ph.D.

2 Edgewater Drive Norwood

MA 02062, USA.

Tel: 7812693756

Fax: 7812693220 ;

Email: w.zhang@siemens.com

Received: 13 August 2011; | Revised: 25 August 2011; | Accepted: 19 September 2011

\begin{abstract}
Magnesium assays are being increasingly requested in hospitals and clinical research institutions. The ionized form of magnesium (iMg) is regarded as the biologically active fraction. Ionophore-based potentiometric sensors can determine $\mathrm{iMg}$ and apply a selectivity correction for co-existing interfering electrolytes, e.g. $\mathrm{Ca}^{2+}$. This technology has been used in several commercial blood analyzers for measuring iMg in whole blood samples. This report reviews the utility of iMg in clinical settings with emphasis on point of care (POC) application, potentiometric $\mathrm{Mg}^{2+}$ sensor technology and challenges and opportunities for future ionized magnesium assays.
\end{abstract}

Keywords: ionized magnesium; hypomagnesemia; sensors; blood gas analyzers point-of-care testing.

\section{Introduction}

Magnesium (Mg) is the fourth most common metal in the human body and is the major intracellular divalent cation that plays an important role in chemical and biochemical processes. Recent experimental, epidemiological and clinical investigations have increased awareness of the range of biological functions of this "forgotten mineral" which include hundreds of enzymatic reactions, ion channel stabilization, energy metabolism, and contraction of myocardial muscle cells. The benefits of $\mathrm{Mg}$ testing on critically ill patients in acute admission, medical therapy, or cardiac surgery have been recognized $[1,2,3]$ to play a role in preventing the development of serious and potentially fatal complications, especially for patients with poor food intake, malabsorption disorders, hypokalemia, hypocalcemia, alcoholism, or for those taking diuretics or other drugs associated with hypomagnesemia [4]. It wasn't until the mid 1990's when $\mathrm{Mg}^{2+}$ ion-selective electrodes became available for testing ionized magnesium (iMg) in blood samples that the use of $\mathrm{iMg}$ as a clinical diagnostic parameter began to be 
extensively investigated. Many reviews have been published concerning $\mathrm{Mg}$ and $\mathrm{iMg}$ in general biological processes and specific pathological applications [5, 6]. G. Sanders et al. [7] published a special review on $\mathrm{iMg}$ and disease, which classified six major clinical situations related to $\mathrm{Mg}$ : renal disease, hypertension, preeclampsia, diabetes mellitus, cardiac disease, and the administration of therapeutic drugs. In 2000, Saris et al. [8] reviewed the role of $\mathrm{iMg}$ in clinical medicine, nutrition and physiology and summarized current analytical technologies for $\mathrm{iMg}$ and total magnesium $(\mathrm{TMg})$ assays.

The human body contains $1000 \mathrm{mmol}(24 \mathrm{~g}$ ) of $\mathrm{Mg}$ of which ca. $60 \%$ is present in bone. The remaining $40 \%$ is nearly equally distributed between skeletal muscle and other tissues like heart and liver. Only $1 \%$ of total body $\mathrm{Mg}$ is extracellular and its concentration is equal to the $\mathrm{Mg}$ concentration in the vascular compartment [9]. $\mathrm{Mg}$ (intra- and extracellular) exists in three states: (a) a free, ionized fraction (the physiologically active form); (b) complexed to anions, e.g., phosphate, bicarbonate, and citrate; (c) protein bound (mainly to albumin), the fraction which is non-ultrafilterable. The equilibrium between free and bound magnesium is influenced by temperature, ionic strength, $\mathrm{pH}$ and other ions competing with $\mathrm{Mg}$ for protein binding sites and chelators. Under normal physiological conditions in extracellular fluid, free iMg comprises 59-72\% of $\mathrm{TMg}$, protein bound $23-31 \%$ and the remaining $5-11 \%$ is complexed with anions. These three fractions of $\mathrm{Mg}$ are in equilibrium with each other. The iMg fraction has major functional physiological roles including nerve conduction, skeletal, cardiac or uterine muscle contraction, as an ion channel adjuster, and serves as a cofactor for hundreds of enzymes. The $\mathrm{iMg}$ reference range is 0.45 to $0.66 \mathrm{mmol} / \mathrm{L}$. Over the years, many different methods have been developed for determining $\mathrm{Mg}$ and its fractions ( $\mathrm{TMg}$ and $\mathrm{iMg}$ ) in blood samples (whole blood and serum/plasma). In 1934, the first colorimetric method for measuring $\mathrm{Mg}$ in biological fluids was described by Hirschfelder and Serles, [10] and this approach is still in use today. Other methods include enzymatic [11, 12], fluorometry (13), flame-emission spectroscopy and atomic absorption spectroscopy (AAS) [14] based methods. The latter approach has been proposed as the reference method for the determination of $\mathrm{iMg}$ in human serum/plasma [15]. Alternatively, in situ analysis can be carried out by X-ray fluorescence [16], and ${ }^{31} \mathrm{P}$ or ${ }^{25} \mathrm{Mg}$-NMR spectroscopy is used for measuring intracellular $\mathrm{Mg}$ concentrations [17]. Although most of these methods are available clinically for determination of $\mathrm{TMg}$ in serum, plasma, urine, cerebral spinal fluid and other body fluids, none of them can determine iMg [9]. Until the development of $\mathrm{Mg}^{2+}$ ion selective electrodes (Mg-ISEs), the only method for assessing $\mathrm{iMg}$ in biological samples was ultrafiltration. While this process is capable of measuring free $\mathrm{Mg}^{2+}$, it faces multiple problems including $\mathrm{pH}$ control and the need for a large sample volume. Additionally, the $\mathrm{Mg}^{2+}$-anion complexes (bicarbonate, phosphate, citrate, etc) are filterable, testing an ultrafiltrate does not exclude $\mathrm{Mg}^{2+}$-anion complexes when attempting to measure only iMg.

With increasing knowledge around the importance of $\mathrm{Mg}$ in biological processes, new $\mathrm{iMg}$ sensors are expected to meet clinical diagnostic requirements, especially POC applications where rapid results $(<120 \mathrm{~s})$, small sample volumes $(<150 \mu \mathrm{L}$ ), and easy to use instruments requiring minimal maintenance are essential [25, 26].

\section{IMg testing for point of care diagnostics}

Although iMg is the most useful indicator for evaluating $\mathrm{Mg}$ status in blood, in most cases only $\mathrm{TMg}$ is measured in clinical laboratories. Measurements are made in plasma or serum by AAS or colorimetry. The $\mathrm{TMg}$ reference range in plasma and serum is 0.66 - $1.06 \mathrm{mmol} / \mathrm{L}$. Although TMg assays are commercially available in many central lab analyzers, e.g. Cobas ${ }^{\circledR}$ (Roche), Advia® (Siemens), Architect ${ }^{\circledR}$ (Abbott) and Synchron ${ }^{\circledR}$ (Beckman Coulter), they are not easily applied to POC testing applications, e.g., testing in ED, OR, ICU and ambulance environments. Recent clinical studies [3] demonstrated the association of hypomagnesemia and mortality rates [6] in ICU patients experiencing hemodialysis [18], type 2 diabetes 
[19], cardiovascular diseases [20], cardiovascular deaths, and medical surgical intensive care [21]. Monitoring and controlling iMg may be more relevant in patient care than $\mathrm{TMg}$, especially when an abnormal protein concentration can be expected, as is often seen for critically ill patients [22, 23]. Notably, a weak correlation has been found between iMg and $\mathrm{TMg}$ in blood samples of patients requiring evaluation of their $\mathrm{Mg}$ status [24].

In heart disease patients, $\mathrm{Mg}$ deficiency contributes to coronary vasospasm, arrhythmias, fibrillation, infarction, and sudden death [5]. A study on $\mathrm{Mg}$ intervention during cardiopulmonary bypass operations [27] showed that intraoperative correction of $\mathrm{iMg}$ is associated with a reduction in postoperative ventricular arrhythmia and maintenance of an uninterrupted sinus rhythm. In this study, the $\mathrm{iMg}$ concentration was monitored using an ISE and adjusted by administering $\mathrm{MgSO}_{4}$ during open-heart surgery. An investigation on patients with traumatic brain injuries [28] indicated that blood iMg significantly declined by $29 \%$ to sub-therapeutical levels at 30 min post-injury and remained depressed for the next $24 \mathrm{hr}$. In contrast, no change was observed for blood $\mathrm{TMg}$ which remained constant for the duration of the study. POC testing on $\mathrm{iMg}$ rather than TMg has been proposed to be a predictor of the long-term neurobehavioral outcome following head injury and ischemia stroke [29, 30, 31]. Clinical trial results $[32,33,34]$ suggest a benefit for $\mathrm{Mg}$ therapy for acute stroke patients in the ambulance or ED within the first two hours of the onset of stroke symptoms. $\mathrm{Mg}$ monitoring is also advocated in preeclampsia $[35,36]$, in a condition reported to be linked with hypomagnesemia [37, $38,39,40]$ and which occurs in 5-7 \% of pregnancies in Europe and the USA. Magnesium sulfate treatment has been used successfully for more than 80 years to minimize the increased vascular reactivity, hypertension, cerebral ischemia, premature labor, and convulsions that are associated with this condition. Very recently, Apostol et al. [41] reported findings suggesting that the ratio of $\mathrm{iCa}: \mathrm{iMg}$ is a crucial diagnostic parameter for prevention of vascular and neurological complications in preeclampsiaeclampsia patients. In critically ill patients, hypomagnesemia is frequently found upon admission to the ICU, a typical POC testing location, and Soliman et al. [3] reported a correlation between the onset of ionized hypomagnesemia during ICU stays and high morbidity and mortality rates. This work noted that $\mathrm{iMg}$ is a stronger predictor for hypomagnesemia outcomes compared to $\mathrm{TMg}$.

The current low level iMg assay requests in clinical practice is partially attributable to poorly defined clinical parameters and interpretative guidelines of $\mathrm{iMg}$ relative to total $\mathrm{Mg}$ as well as the lack of reliable and convenient methods for measuring iMg compared to $\mathrm{TMg}$.

\section{Potentiometric iMg sensors in clinical analyzers}

\subsection{Ionophores and selectivity}

All commercial iMg sensors are based on neutral ionophore-based potentiometric $\mathrm{Mg}^{2+}$ sensors. The features of the ionophore determine the Mg-ISE performance (sensitivity, selectivity against interference, response time, and use lifetime). Development of $\mathrm{Mg}^{2+}$ ionophores started in the 1980s and the exploration for selective ionophores in Simon's group at ETH Zurich led to identification of more than 50 compounds [42].

The charge, radius, polarity and the polarizability of $\mathrm{Mg}$ determines the nature of its interaction with the ionophore (Table 1). $\mathrm{Mg}^{2+}$ has highest charge density among common cations and is preferentially complexed in an aqueous environment by anions with a high charge density, e.g., ATP $^{4-}$, oxalate, malonate. The octahedrallycoordinated water of hydration is more difficult to displace for $\mathrm{Mg}^{2+}$ than $\mathrm{Ca}^{2+}$ and other alkaline earth cations. The major challenge in $\mathrm{Mg}^{2+}$ ionophore development is to obtain selectivity for $\mathrm{Mg}^{2+}$ over all other cations. $\mathrm{Mg}^{2+}$ has a higher free energy of hydration (1898 $\mathrm{kjmol}^{-1}$ ) than other mono- and divalent cations. To interact with $\mathrm{Mg}^{2+}$ in aqueous samples, the ISE membrane has to compensate for this high $\Delta \mathrm{G}_{\text {hydration }}$ through the strength of the ionophore binding with $\mathrm{Mg}^{2+}$ and through the subsequent transfer of the $\mathrm{Mg}^{2+}$ ionophore complex to the electrode membrane solvent. 
Table 1. Alkali and alkaline earth cations [43]

\begin{tabular}{|l|l|l|l|l|l|}
\hline Cation & $\begin{array}{l}\text { Ionic radius } \\
(\AA)\end{array}$ & $\begin{array}{l}\text { Hydration } \\
\text { number }\end{array}$ & $\begin{array}{l}\text { Surface charge } \\
\text { density }\left(\AA^{-3}\right)\end{array}$ & $\begin{array}{l}\text { Polarizability } \\
\left(\AA^{3}\right)\end{array}$ & $\begin{array}{l}-\Delta \mathrm{G}_{\text {hydration }} \\
\left(\mathrm{kjmol}^{-1}, 25{ }^{\circ} \mathrm{C}\right)\end{array}$ \\
\hline $\mathrm{Li}^{+}$ & 0.76 & 6 & 0.13 & 0.03 & 510 \\
\hline $\mathrm{Na}^{+}$ & 1.02 & 6 & 0.08 & 0.3 & 412 \\
\hline $\mathrm{K}^{+}$ & 1.38 & 6 & 0.04 & 1.1 & 336 \\
\hline $\mathrm{Mg}^{2+}$ & 0.72 & 6 & 0.26 & 0.2 & 1898 \\
\hline $\mathrm{Ca}^{2+}$ & 1.12 & 8 & 0.14 & 0.9 & 1584 \\
\hline
\end{tabular}

For $\mathrm{Mg}^{2+}$, the binding strength of various ligands is ester < ether < phosphate < amide < amine, which is based on the donicity values of simple organic molecules in Lewis acid-base theory [44]. On this basis several types of $\mathrm{Mg}$ ionophores were designed and developed (Figure 1). Most Mg ionophores contain (i) diamide side chains, which offer selective binding sites for alkaline earth cations (e.g., $\mathrm{Mg}^{2+}, \mathrm{Ca}^{2+}$ ) against alkali cations (e.g., $\mathrm{Na}^{+}, \mathrm{K}^{+}$); (ii) lipophilic subunits at the terminals of the side chains, which offers adequate lipophilicity for the $\mathrm{Mg}$-ionophore complex; (iii) stereo-structured side chains with spacer units designed to maximize the selectivity for $\mathrm{Mg}^{2+}$.

Modern potentiometric sensors based on polymer membranes exhibit well-defined ionexchange properties, and the sensor response may in many cases be quantitatively described by the phase boundary potential model of the Galvanic potential between the aqueous sample and the membrane phase [45]. This model has been used to relate the selectivity coefficients of potentiometric magnesium sensors to underlying thermodynamic parameters including complex formation constants and stoichiometry [46]. Since the stoichiometry of ionophore:cation complexes may be different for $\mathrm{Mg}^{2+}$ and $\mathrm{Ca}^{2+}$ (the main interfering cation to $\mathrm{Mg}^{2+}$ in blood sample analysis), $\mathrm{Mg}^{2+}$ and $\mathrm{Ca}^{2+}$ can be differentiated in their potentiometric responses by adjusting the concentration of the lipophilic anion salt in the sensor membrane formulation [47, 48]. For example, tripodal structured $\mathrm{Mg}^{2+}$ ionophores, or tris(malondiamides), e.g. ETH 7025, ETH 3832, ETH 5506 and ETH 5504, form 1:1 complexes with $\mathrm{Mg}^{2+}$ and 2:1 complexes with $\mathrm{Ca}^{2+}$. The modeling of mass balance and electrostatic balance in the interfacial exchange of cation and cation-ionophore complexes leads to the optimal theoretical molal ratio of 1.5 (lipophilic sites:ionophore) for the best selectivity of $\mathrm{Mg}^{2+}$ over $\mathrm{Ca}^{2+}$ [46], which has been verified experimentally. The most selective ionophores in this class are ETH 5506 and ETH 5504 with selectivity coefficients against $\mathrm{Ca}^{2+}$ of $10^{-2.3}$ (Separate Solution Method, or SSM). In the mid 1990s, a group of double-armed, diazacrown ether based ionophores were developed by Suzuki et al. [49] which provide a hydrophilic space for cations to fit inside the ring cavity. The optimal lipophilic sites:ionophore molal ratio is 1.0 which indicates that these ionophores form $\mathrm{Mg}^{2+}$ and $\mathrm{Ca}^{2+}$ complexes of the same stoichiometry (2:1). Among these ionophores, K22B5 has the highest selectivity against $\mathrm{Ca}^{2+}$ of $10^{-2.6}$ (SSM). However, this ionophore has a lower lipophilicity $\left(\log P_{\mathrm{TLC}}=\right.$ $3.5 \pm 0.6)$ compared to ETH ionophores $\left(\log P_{\mathrm{TLC}}\right.$ $=8.48 \pm 0.98$ ) [46], leading to their leaching from the sensor membrane which adversely affects both the sensor's use lifetime and shelf lifetime.

However, even sensors which use the best performing $\mathrm{Mg}$ ionophores, e.g., ETH 5506, K22B5, struggle to meet the clinical requirements $[50,51,52]$ of selectivity against the major interfering cations, i.e., $\mathrm{Ca}^{2+}, \mathrm{Na}^{+}$and $\mathrm{K}^{+}$(Table 2). 


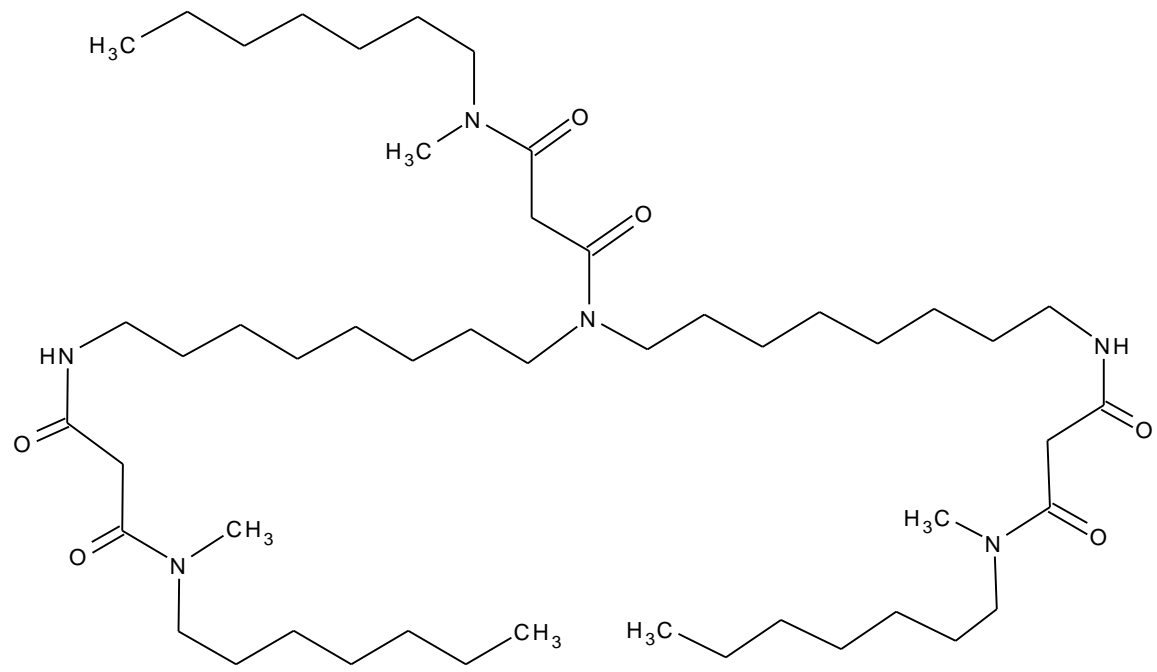

ETH 7025

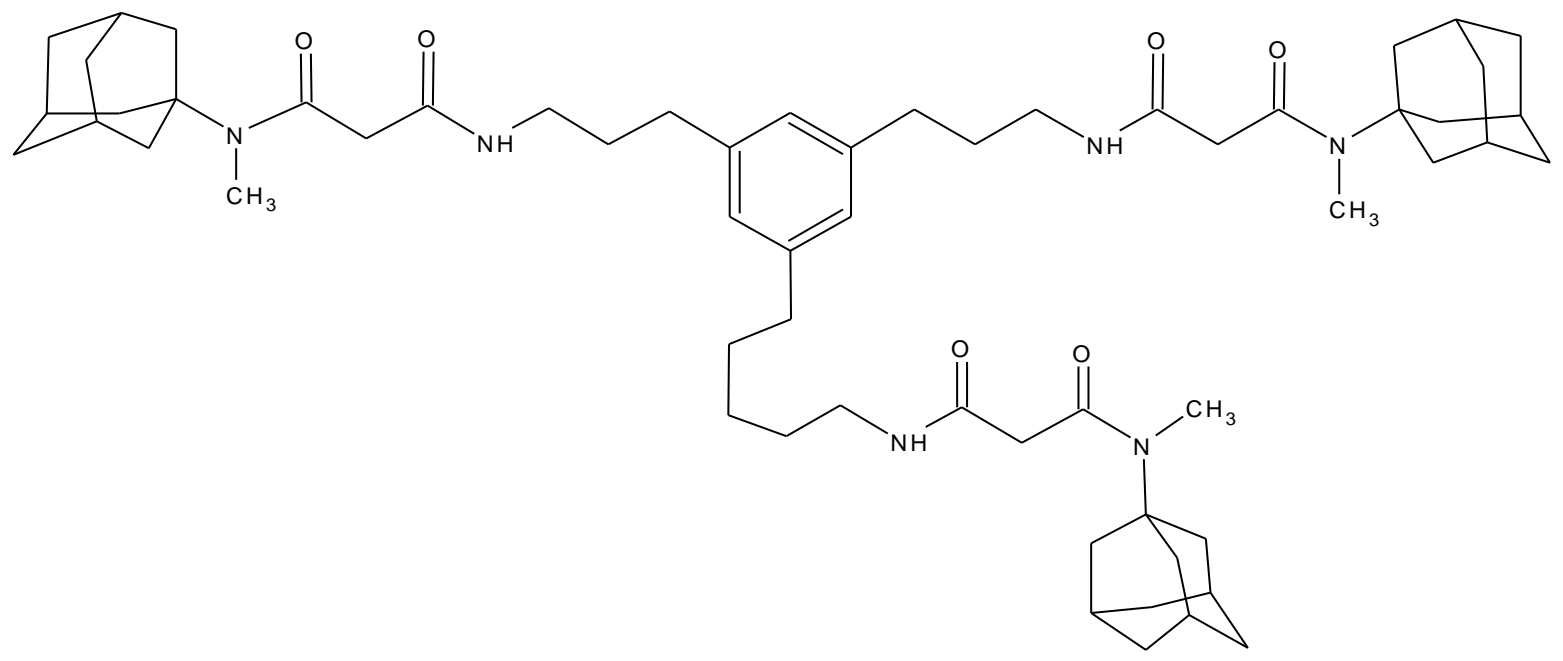

ETH 5506

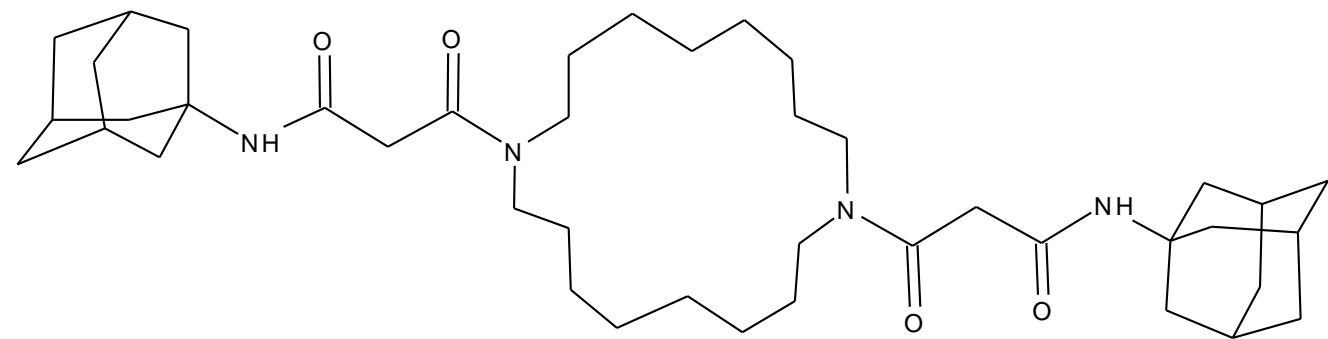

K22B5

Figure 1. $\mathrm{Mg}^{2+}$-selective ionophores 
Table 2. Normal adult clinical ranges of the main cation electrolytes in blood and the required selectivity coefficients assuming a $1 \%$ allowable error. The calculations are based on the traditional NicolskyEisenman equation. [50)

\begin{tabular}{|c|c|c|c|}
\hline & $\begin{array}{c}\text { Reference interval } \\
(\mathrm{mmol} / \mathrm{L} \text { plasma) }\end{array}$ & $\begin{array}{c}\text { Required selectivity } \\
\text { coefficient for iMg } \\
\text { (without calibration*) }\end{array}$ & $\begin{array}{c}\text { Required selectivity } \\
\text { coefficient for iMg } \\
\text { (with calibration*) }\end{array}$ \\
\hline $\mathrm{Na}^{+}$ & $134-143$ & -3.9 & -2.7 \\
\hline $\mathrm{K}^{+}$ & $3.3-4.8$ & -1.0 & -0.5 \\
\hline $\mathrm{Ca}^{2+}$ & $1.00-1.26$ & -2.5 & -1.7 \\
\hline $\mathrm{Mg}^{2+}$ & $0.46-0.66$ & - & -- \\
\hline
\end{tabular}

For direct measurement of blood with $\mathrm{iMg}$ sensors, selectivity against $\mathrm{Ca}^{2+}$ is the major challenge since extracellular $\mathrm{Ca}^{2+}$ concentrations (1.0-1.26 mmol/L) are much higher than $\mathrm{Mg}^{2+}$ concentrations $(0.46-0.66 \mathrm{mmol} / \mathrm{L})$. This requires an $\mathrm{iMg}$ sensor with a high $\mathrm{Mg}^{2+}$ selectivity over $\mathrm{Ca}^{2+}$ to ensure sufficient accuracy in reporting $\mathrm{iMg}$, especially for low $\mathrm{Mg}^{2+}$ samples (hypomagnesemia). Inaccuracy in $\mathrm{iMg}$ measurements is minimized if the sensor is calibrated with calibrators containing physiological concentrations of the interfering compounds $\left(\mathrm{Ca}^{2+}, \mathrm{K}^{+}\right.$and $\left.\mathrm{Na}^{+}\right)$. Additional inaccuracies can be caused by variations in the activity of the interfering species. This interference can be minimized by chemometric correction of the analyte signal based on measurements of the activity of the cations. However, the selectivity of each sensor must be sufficiently high in order to avoid the propagation of errors.

\subsection{Challenges of iMg sensors in blood analyzers}

Since the 1990s, three diagnostic companies have commercialized $\mathrm{Mg}^{2+}$ selective electrodes for $\mathrm{iMg}$ assays in blood, serum or plasma. The platforms are KONE Microlyte 6 (Kone Instruments, Espoo, Finland); AVL 988/4 (AVL Medical Instruments (now Roche Diagnostics), Graz, Austria), and Nova CRT, CCX (Nova Biomedical, Waltham, MA, USA). Nova's iMg sensor is the only one currently available in commercial products.
Although iMg sensors in these commercial analyzers meet the general requirements for blood assays in normal clinical situations, some performance issues have raised concern. One study showed different $\mathrm{iMg}$ reference intervals across the three platforms [53] with KONE and AVL showing the closest agreement (likely because of similarities between their ionophores and electrode designs (AVL: ETH 7025; Kone: ETH 5220). Nova's iMg results were $0.11 \mathrm{mmol} / \mathrm{L}$ higher than AVL and KONE and different selectivity patterns against $\mathrm{Ca}^{2+}$ and monovalent cations were observed between the NOVA and AVL iMg sensors [54, 55].

The AVL 988/4 analyzer was susceptible to the so-called "silicone interference" which can devastate iMg results [55]. This effect arises when blood is collected in BD Vacutainer plastic tubes containing clot activator and silicone as the stopper lubricant (serial no. 367820) as opposed to using a BD glass tube with glycerol lubricant on the stopper. The silicone substance and clot activator from the Vacutainer tube are believed to affect the iMg sensors surface lipophilic characteristics. A working hypothesis was made that one or several molecular layers of the extremely non-polar silicone material could form an additional barrier for the transition of the very polar magnesium ion to the membrane phase, where other less polar ions, such as calcium and sodium would transit the interface between solution and membrane more easily and, therefore, are preferred. The membrane would sense more interfering ions than magnesium ions. 
NOVA's iMg sensor showed an overestimation of $\mathrm{Mg}^{2+}$ at very low $\mathrm{Mg}$ concentrations ( $\mathrm{TMg}<0.35 \mathrm{mmol} / \mathrm{L}$ ), and in samples containing a low $\mathrm{TMg} / \mathrm{TCa}$ ratio of 0.16 [56]. This could be due to an improper chemometric correction of the $\mathrm{Ca}$ interference on the $\mathrm{Mg}$ electrode, non-linearity, or inadequate calibration. The failure of the product to correctly measure severe hypomagnesemic samples "erodes its diagnostic usefulness". Furthermore, such iMg sensors exhibit significant interference from thiocyanate $\left(\mathrm{SCN}^{-}\right)$an analyte is commonly found in smoker's blood [57]. The AVL iMg sensor was not affected by the presence of $\mathrm{SCN}^{-}$. The authors speculate that the NOVA interference by $\mathrm{SCN}^{-}$ may result from the absence of anionic sites in the membrane of the Nova iMg sensor, in which anion species like $\mathrm{SCN}^{-}$may be easily exchanged. The addition of lipophilic salts (e.g., tetraphenyl borate) may minimize the effect of $\mathrm{SCN}^{-}$and indeed some improvements on the Nova iMg sensor performance have been reported, especially at higher blood iMg concentrations [58].

A number of studies have reported reliable results between three analyzer types, while others have shown marked analyzer-specific variations $[59,60)$. Such variations and discrepancies have partially contributed to the lack of agreement of clinical interpretations regarding ionized magnesium results. Nevertheless, the availability of $\mathrm{Mg}^{2+}$-selective electrodes does now make it possible to directly measure blood iMg for in vitro diagnostics and clinical investigations. Clearly, the clinical demands of blood $\mathrm{iMg}$ assays require further development of $\mathrm{iMg}$ sensors with high reliability, fast response, easy maintenance, and long use lifetimes.

Currently, there is no reference method for determining the $\mathrm{iMg}$ in blood [54, 55]. Several authors [54, 61, 62] have suggested using a combination of ultrafiltration and AAS as a reference method, however, these ultrafiltration methods measure "free" $\mathrm{Mg}$, not $\mathrm{iMg}$ since anioncomplexed $\mathrm{Mg}$ is also contained in the ultrafiltrate. One possible reference method for $\mathrm{iMg}$ is currently in development [63].

\subsection{Other factors affecting iMg sensors}

Since current iMg sensors cannot provide adequate selectivity for $\mathrm{Mg}^{2+}$ over $\mathrm{Ca}^{2+}$ and/or $\mathrm{Na}^{+}$ in the presence of pathophysiological electrolyte concentrations, chemometric corrections are needed to compensate for these interferences. In addition to iMg, on-board sensors and calibration are required for $\mathrm{Ca}^{2+}, \mathrm{Na}^{+}$, and $\mathrm{K}^{+}$at a minimum. Most calculations around calibrations and sample testing are based on the empirical NicolskyEisenman equation [64], in which the sensor signal $(\mathrm{mV})$ is proportional to the logarithm of the primary ion activity. Improvements have been made to the original equation to enhance its application to real-life applications $[65,66]$. These chemometric algorithmic correction calculations [67] are based on the response slope, intercept and selectivity obtained from calibration procedures.

IFCC guidelines [68] recommend a blood $\mathrm{iMg}$ assay result to be normalized to $\mathrm{pH} 7.4$ where the $\mathrm{pH}$ of the sample is measured simultaneously [69]. It is well known that as sample $\mathrm{pH}$ increases, the free $\mathrm{Mg}^{2+}$ concentration decreases, due to enhanced binding of $\mathrm{Mg}^{2+}$ with proteins (mainly albumin). In the ultrafilterable fraction, $\mathrm{pH}$ affects the binding of anions e.g. bicarbonate, lactate and phosphate to $\mathrm{Mg}^{2+}$ in a similar way to that seen for $\mathrm{Ca}$ but to a smaller extent $[23,73]$. These effects have been studied exhaustively but discrepancies in results between analyzer types have been observed [70, 71, 72, 74, 75].

In automated blood gas analyzers, surfactants can be present in the calibration rinse/wash, and quality control reagents [76]. Nonionic surfactants based on poly(ethylene oxide), e.g., Brij 35 and Triton X-100, are commonly used. Malinowska et al. [77, 78] found that this type of surfactants can introduce a significant positive signal bias (> 100 $\mathrm{mV}$ ) to $\mathrm{iMg}$ sensors (using ETH 7025 as the ionophore), an effect not observed for iCa sensors and a dramatic loss of selectivity for $\mathrm{Mg}$ which renders direct $\mathrm{iMg}$ measurement virtually impossible. The mechanism may be due to the formation of a thin surfactant film on the sensor surface that alters the electrode partitioning and ion-exchange pattern [79]. This surfactant mechanism may also play a role in the observed interference by silicone on $\mathrm{AVL} \mathrm{iMg}$ sensors discussed in Section 3.2 Accordingly, IFCC's guidelines for measuring $\mathrm{iMg}$ in blood [68], recommend avoiding polyethylene oxide based materials in calibrants or QC standards. Alkyl-N- 
methylglucamide-based nonionic surfactants, e.g., MEGA $8 \AA$, may cause less interference but suffer from an increased cost as well as low foaming features. Recently, a proprietary surfactant based on acetylenic diols (AD) was investigated for $\mathrm{iMg}$ sensor applications (ETH 5506 as ionophore). But the iMg sensor showed a "memory effect" [80). Studies on another proprietary nonionic surfactant based on poly(ethylene oxide) [81] indicate that in a narrow concentration range, the surfactant can be used in calibration reagents giving an acceptable selectivity and sensitivity, and a fast and stable response over clinically relevant $\mathrm{iMg}$ concentrations.

\section{Conclusion}

Increased recognition of the clinical importance of $\mathrm{iMg}$ over the last 30 years has resulted in greater demand for reliable iMg testing in the POC diagnostics field. The development of neutral ionophore based potentiometric sensors has made it possible to directly measure $\mathrm{iMg}$. Interference from other cations, notably $\mathrm{Ca}^{2+}$, can be corrected by chemometric calculations with selectivity coefficients obtained from concomitant calibrations. Current commercial iMg sensors still face multiple challenges in reporting accurate and precise results for hypomagnesemia samples, in addition to being practical for routine POC use by combining adequate use lifetimes with easy operation and minimal maintenance. A standard reference method for iMg in blood is still required. These challenges have to date limited the utility of $\mathrm{iMg}$ testing in clinical settings and have hindered $\mathrm{iMg}$ academic investigations. With the advances in sensor technology and analyzer automation that have occurred in recent years, future iMg sensors are expected to be more reliable and practical for widespread adoption of $\mathrm{iMg}$ testing in POC applications.

\section{Acknowledgements}

The author would like to thank Ms. Laura Uretsky, Mr. Kevin Horan, Dr. Chris Lawrence and Dr. John Benco for comments and editing on this manuscript.

\section{References}

1. Altura B.M., Altura B.T., Magnesium: Forgotten Mineral in Cardiovascular Biological and Atheroenesis in New Perspectives in Magnesium Research. Eds: Y. Nishizawa, H. Morii, J. Durlach, Springer, London, 2007, 239.

2. Sen A.P., Gulati A., Use of Magnesium in Traumatic Brain Injury. Neurotherapeutics 2010, 7, 91. doi:10.1016/j.nurt.2009.10.014

3. Soliman H.M., Mercan D., Lobo S.S., Melot C., Vincent J.L., Development of ionized hypomagnesemia is associated with higher mortality rates. Crit. Care. Med. 2003, 31, 1082.

4. Toffaletti J.G. Controlling Magnesium in Surgery, Intensive Care, and Beyond. Point of Care, $2007, \quad 6, \quad 129$. doi:10.1097/01.poc.0000271402.14936.9b

5. Chakraborti S., Charkraborti T., Mandal M., Mandal A., Das S., Ghosh S., Protective role of magnesium in cardiovascular diseases: A review. Mol. Cell. Biochem. 2002, 238, 163.

6. Escuela M.P., Guerra M., Anon J.M., MartinezVizcaino V., Zapatero M.D., Garcia-Jalon A., Celaya S., Total and ionized serum magnesium in critical ill patients. Intensive Care Med. 2005, 31, 151. doi:10.1053/jcrc.2000.0150036

7. Sanders G., Huijgen H.J., Sanders R., Magnesium in Disease: a review with Special Emphasis on the Serum Ionized Magnesium. Clin. Chem. Lab. Med. 1999, 37, 1011. doi: 10.1515/CCLM.1999.151

8. Saris N.L., Mervaala E., Karppanen H., Khawaja J.A., Lewenstam A., Magnesium An update on physiological, clinical and analytical aspects. Clin. Chim. Acta 2000, 294, 1.

9. Elin R.J., Assessment of Magnesium Status. Clin. Chem. 1987, 33, 1965.

10. Hirschfelder A.D., Serles E.R., A simple adaptation of Kolthoff's colorimetric method for the determination of magnesium in biological fluids. J. Biol. Chem. 1934, 104, 635.

11. Tabata M., Kido T., Totani M., Murachi T., Direct spectrophotometry of magnesium in serum after reaction with hexokinase and 
glucose-6-phosphate dehydrogenase. Clin. Chem. 1985, 31, 703.

12. Wimmer M., Artiss J., Zak B., A kinetic colorimetric procedure for quantifying magnesium in serum. Clin. Chem. 1986, 32, 629.

13. Ioannuo P., Konstantianos D., Fluorometric determination of magnesium in serum with 2hydroxy-1naphthaldehyde salicyloylhydrazone. Clin. Chem. 1989, 35, 1492.

14. Teloh H., Estimation of magnesium in serum by means of flame spectrophotometry. Am. J. Clin. Pathol. 1958, 30, 129.

15. Kuelpmann W., Ruschke D., Buettener J., Paschen K., A Comparison of Reference Method Values for Calcium, Lithium and Magnesium with Method-Dependent Assigned Values. J. Clin.. Chem. Clin. Biochem, 1989, 27, 33.

16. Ausserer W., Ling Y., Chandra S., Morrison G., Quantitative imaging of boron, calcium, magnesium, potassium, and sodium distributions in cultured cells with ion microscopy. Anal. Chem. 1989, 61, 2690. doi: 10.1007/978-1-60761-746-4_6

17. Gupta R.K., Benovic J.L., Rose Z.B., The determination of the free magnesium level in the human red blood cell by ${ }^{31} \mathrm{P}$ NMR. J. Biol. Chem. 1978, 253, 6172.

18. Isimura E., Okuno S., Yamakawa T., Inaba M., Nishizawa Y., Serum magnesium concentration is a significant predictor of mortality in maintenance hemodialysis patients. Magnesium Res. 2007, 20, 237.

19. Curiel-Garcia J.A., Rodrigues-Moran M., Guerrero-Romero F., Hypomagnesemia and mortality in patients with type 2 diabetes. Magnesium Res. 2008, 21, 163.

20. Soliman H., Mercan D., Lobo S.S.M., Melot C., Vincent J.L., Development of ionized hypomagnesemia is associated with higher mortality rates. Crit. Care Med. 2003, 31, $1082 . \quad$ doi: 10.1097/01.CCM.0000060867.17556.A0

21. Shirey T., Monitoring magnesium to guide magnesium therapy for heart surgery. $J$. Anesth 2004, 18, 118.
22. Kuelpmann W., Rossler J., Brunkhorst R., Schueler A., Ionized and total magnesium serum concentrations in renal and hepatic diseases. Eur. J. Clin. Chem. Clin. Biochem. 1996, 34, 257. doi: $10.1515 / \mathrm{cclm} .1996 .34 .3 .257$

23. Filos D., Okorodudu A. A method for the measurement of ionized magnesium. Lab. Med. 1995, 26, 70.

24. Johansson M., Whiss P., Weak relationship between ionized and total magnesium in serum of patients requiring magnesium status. Biological Trace Element Research, 2007, 115, 13.

25. Ryu H., Crisis or Calm? Point-of-Care Navigations the Economic Downturn. Point of Care: the Journal of Near-Patient Testing \& Technology 2009, 8, 149. ㅇi: 10.1097/POC.0b013e3181c0ef1e

26. Gregory K., Lewandrowski K., Management of a Point-of-Care Testing Program. Clin. Lab. Med. 2009, 29, 433.

27. Wilkes N.J., Mallett S.V., Peachey T., Di Salvo C., Walesby R., Correction of ionized plasma magnesium during cardiopulmonary bypass reduces the risk of postoperative cardiac arrhythmia. Anaesth. Analg. 2002, 95, 828.

28. Bayeyre F., Saatman K., Helfaer M., Sinson G., Weisser J., Brown A., McIntosh T., Alterations in ionized and total blood magnesium after experimental traumatic brain injury: relationship to neurobehavioral outcome and neuroprotective efficacy of magnesium chloride. J. Neurochem. 1999, 73, 271.

29. Memon R., Altura B., Benjamin J., Cracco R., Altura B., Predictive value of serum ionized but not total magnesium levels in head injuries. Scand. J. Clin. Lab. Invest. 1995, 55, 671.

30. Kahraman S., Ozgurtas T., Kayali H., Atabey C., Kutluay T., Timurkaynak E.. Monitoring of serum ionized magnesium in neurosurgical intensive care unit: preliminary result. Clin. Chim. Acta 2003, 334, 211. doi:10.1016/S0009-8981(03)00235-3

31. Ohira T., Peacock J.M., Iso H., Chambless L.E., Rosamond W.D., Folsom A.R., Serum and dietary magnesium and risk of ischemic 
stroke. Am. J. Epidemiology 2009, 169, 1437. doi:10.1093/aje/kwp071

32. Schlueter G., Nye P., Morales-Tatgenhorst D., Maria T., Fitzgerald J., Saver J., Starkman S., Redefining Hyper Acute: Delivering Neuroprotectants within Two Hours of Stroke Symptom Onset. Stroke 2006, 37, 750.

33. Dhandapani S.S., Gupta A., Vivekanandhan S., Sharma B., Mahapatra A.K., Randomized controlled trial of magnesium sulphate in severe closed traumatic brain injury. Ind. J. Neurotrauma 52008, 5, 27.

34. Mendez D.R., Corbett R., Macias C., Laptook A., Total and ionized plasma magnesium concentrations in children after traumatic brain injury. Pediatr. Res. 2005, 57, 347. doi: 10.1203/01.PDR.0000150803.36315.FF

35. Taber E., Tan L., Chao C., Bella M., Ross M., Pharmacokinetics of ionized versus total magnesium in subjects with preterm labor and preeclampsia. Am. J. Obstet. Gynecol. 2002, 186, 1017.

36. Yoshida M., Matsuda Y., Akizawa Y., Ono E., Ohta H., Serum ionized magnesium during magnesium sulfate administration for preterm labor and preeclampsia. Eur. J. Obstet. Gyn. \& Reprod. Biol. 2006, 128, 125.

37. Hirschfelder A.D., Haury V.A., Clinical manifestation of high and low plasma magnesium. J. Am. Med. Assoc 1934, 102, 1138. doi: 10.1001/jama.1934.02750140024010

38. Hall D.G., Serum magnesium in pregnancy. Obst. Gynecol. 1957, 9, 158.

39. Song Y., Manson J., Cook N., Albert C., Buring J., Liu S., Dietary magnesium intake and risk of cardiovascular disease among women. Am. J. Cardiol. 2005, 96, 1135. doi:10.1016/j.amjcard.2005.06.045

40. Handwerker S.M., Altura B.T., Altura B.M.. Serum ionized magnesium and other electrolytes in the anternatal period of human pregnancy. J. Am. Coll. Nutr. 1996, 15, 36.

41. Apostol A., Apostol R., Ali E., Choi A., Ehsumi N., Hu B., Li L., Altura B., Cerebral spinal fluid and serum ionized magnesium and calcium levels in preeclampsic women during administration of magnesium sulfate. Fertil. Steril. 2010, 94, 276.
42. Spichiger U.E., History of the Development of Magnesium-selective Ionophores and Magnesium-selective Electrodes. Electroanal. 1993, 5, 739. doi: 10.1002/elan.1140050906

43. Noyes, R.M., Thermodynamics of Ion Hydration as a Measure of Effective Dielectric Properties of Water. J. Am. Chem. Soc. 1962, 84, 513.

44. Jensen W.B., The Lewis Acid-Base concepts. J.Wiley \& Sons New York, 1980, Chapter 7.

45. Bakker E., Nagele M., Schaller U., Pretsch E., Applicability of the phase boundary potential model to the mechanistic understanding of solvent polymeric membrane-based ionselective electrodes. Electroanal. 1995, 7, 817. doi: 10.1002/elan1140070906

46. Zhang W., Jenny L., Spichiger U.E., A Comparison of Neutral $\mathrm{Mg}^{2+}$-Selective Ionophores in Solvent Polymeric Membranes: Complex Stoichiometry and Lipophilicity. Anal. Sci. 2000, 16, 11.

47. Rosatzin T., Bakker E., Suzuki K., Simon W., Lipophilic and immobilized anionic additives in solvent polymeric membranes of cationselective chemical sensors. Anal. Chim. Acta 1993, 280, 197. doi:10.1016/00032670(93)85122-Z

48. Eugster R., Gehrig P., Morf W., Spichiger U., Simon W., Selectivity-modifying of anionic sites in neutral-carrier-based membrane electrodes. Anal. Chem. 1991, 63, 2285 (1991). doi: 10.1021/ac00020a017

49. Suzuki K., Watanabe K., Matsumoto Y., Kobayashi M., Sato S., Siswanta D., Hisamoto H., Design and Synthesis of Calcium and Magnesium Ionophores Based on DoubleArmed Diazacrown Ether Compounds and Their Application to an Ion Sensing Component for an Ion-Selective Electrode. Anal. Chem. 1995, 67, 324. doi: $\underline{10.1021 / \mathrm{ac} 00098 \mathrm{a} 016}$

50. Spichiger U.E., Chemical Sensors and Biosensors for Medical and Biological Applications. Wiley-VCH Verlag $\mathrm{GmbH}$ Weiheim, 1998, 160.

51. Zhang W., Fakler A., Demuth C., Spichiger U., Comparison of different methods for determining the selectivity coefficient using a magnesium-selective electrode. Anal. Chim. 
Acta 1998, 30, 211. doi: 10.1016/S00032670(98)00538-8

52. Zhang X., Fakler A., Spichiger U.E. Development of magnesium ion-selective microelectrodes based on new neutral carrier $\mathrm{ETH}^{\mathrm{T}}$ 5504. Electroanal. 1998, 10, 1174. doi: 10.1002/(SICI)1521-4109(199811)

53. Huijgen H.J., Sanders R., Cecco S.A., Rehak N.N., Sanders G.T., Elin R.J., Serum ionized magnesium: comparison of results obtained with three ion-selective analyzers. Clin. Chem. Lab. Med. 1999, 37, 465.

54. Altura B.T., Shirey T., Young CC., Dell'orfano K., Hiti J., Welsh R., Yeh Q., Barbour R., Altura B., Characterization of a New Ion Selective Electrode for Ionized Magnesium in Whole Blood, Plasma, Serum, and Aqueous Samples. Scand. J. Clin Lab Invest. 1994, 54, Suppl. 217, 21.

55. Marsoner H.J., Spichiger U.E., Ritter C., Sachs CH., Ghahramani M., Offenbacher H., Kroneis H., Kindermans C., Dechaux M., Measurement of ionized magnesium with neutral carrier based ISE's. Progress and results with the AVL 988-4 magnesium analyzer. Scand. J. Clin. Lab. Invest. 1994, 54, Suppl. 217, 45.

56. Csako, G., Rehak, N.N., Elin, R.J., Falsely high ionized magnesium results by an ionselective electrode method in severe hypomagnesemia. Eur. J. Clin. Chem. Biochem. 1997, 35, 701.

57. Rehak N., Cecco S., Niemela J., Elin R.J., Thiocyanate in smokers interferes with the Nova magnesium ion-selective electrode. Clin. Chem. 1997, 43, 1595.

58. Hoshine K., Ogawa K., Hishitani T., Kitazawa R., Characteristics of improved NOVA magnesium ion-selective electrode: changes of ionized magnesium values and reference interval in healthy children. Magnesium Res. 2001, 14, 203.

59. Boguschewski F.H., Seyfarth M., Heidrich J.P., Evaluation of two $\mathrm{Mg}^{2+}$-selective electrodes by means of a flow-through device. Clin. Chem. Lab. Med. 2002, 40, 308.

60. Cao Z., Tongate C., Elin R.J., Evaluation of AVL 988/4 analyzer for measurement of ionized magnesium and ionized calcium.
Scand. J. Clin. Lab. Invest. 2001, 61, 389. doi:10.1080/00365510120878

61. Speich M., Bousquet B., Nicolas G., Reference values for ionized, complexed, and proteinbound plasma magnesium in men and women. Clin. Chem. 1981, 27, 246.

62. D'costa M., Cheng P., Ultrafilterable calcium and magnesium in ultrafiltrates of serum prepared with the Amicon MPS-1 system. Clin. Chem. 1983, 29, 519.

63. Berdat D., Andres H., Wunderli S., Development of suitable ISE measurement procedures for SI-Traceable Chemical Activity Determination. Chimia 2009, 63, 670.

64. Nicolsky B.P., Schulz M., Belijustin A., Lev A., in Glass Electrodes for Hydrogen and other Cations. Eisenman G., (Ed.); 1967, M. Dekker: New York.

65. Bakker E., Generalized selectivity description for polymeric ion-selective electrodes based on the phase boundary potential model. $J$. Electroanal Chem. 2010, 639, 1. doi: 10.1016/j.jelechem.2009.09.031

66. Bakker E., Meruve R.K., Pretsch E., Meyerhoff M., Selectivity of Polymer Membrane-Based Ion-Selective Electrodes: Self-Consistent Model Describing the Potentiometric Response in Mixed Ion Solutions of Different Charge. Anal. Chem. 1994, 66, 391. doi: 10.1021/ac00091a600

67. Eugster R., Rusterholz B., Schmid A., Spichiger U.E., Simon W., Characterization procedure for ion-selective electrode assays of magnesium activity in aqueous solutions of physiological composition. Clin. Chem. 1993, $39,855$.

68. IFCC Scientific Division, Committee of Point of Care Testing. Guidelines for sampling, measuring, and reporting ionized magnesium in undiluted serum, plasma or blood. Clin. Chem. Lab. Med. 2005, 43, 564.

69. Csako G., Rehak N., Elin R., Falsely high ionized magnesium results by an ion-selective electrode method in severe hypomagnesemia. Eur. J. Clin. Chem. Clin. Biochem. 1997, 35, 701.

70. Elin R., Hristova E., Cecco S., Niemela J., Rehak N., Comparison of precision and effect of $\mathrm{pH}$ and calcium on the AVL and Nova 
magnesium ion-selective electrodes. Scand. J. Clin. Lab. Invest. 1996, 56, Suppl. 224, 203.

71. Wang S., McDonnell E., Sedor F., Toffaletti J., $\mathrm{pH}$ effects on measurements of ionized calcium and ionized magnesium in blood. Arch. Pathol. Lab. Med. 2002, 126, 947.

72. Ising H., Bertschaft F., Gunther T., Jeremias E., Jeremias A. Measurement of free magnesium in blood, serum, and plasma with ion-selective electrode. Eur. J. Clin. Chem. Clin. Biochem. 1995, 33, 365.

73. Lewenstam A., Blomqvist N., Oest J., Determination and significance of ionized magnesium. Kliin. Lab. 1993, 10, 60.

74. Maj-Zurawska M., Clinical findings on human blood with the KONE ISE for $\mathrm{Mg}^{2+}$. Scand. $J$. Clin. Lab. Invest. 1994, 54, Suppl. 217, 69.

75. Siggard-Andersen O., Thode J., Wandrup J., The concentration of free calcium ions in the blood plasma: "ionized calcium". In: Blood $\mathrm{pH}$, Carbon Dioxide, Oxygen and Calcium-ion. O. Siggard-Andersen, (Ed.). Private Press, 1981, Copenhagen 163.

76. Barton E.C. Advances in Automated Analysis, Technicon International Congress vol. 2, Mediad, Tarrytown, NY, 1977, 39.

77. Malinowska E., Manzoni A., Meyerhoff M., Potentiometric response of magnesium- selective membrane electrode in the presence of nonionic surfactants. Anal. Chim. Acta 1999, 382, $265 . \quad$ doi:10.1016/S00032670(98)00802-2

78. Malinowska E., Meyerhoff M., Influence of nonionic surfactants on the potentiometric response of ion-selective polymeric membrane electrodes designed for blood electrolyte measurements. Anal. Chem. 1998, 70, 1477. doi: 10.1021/ac970761t

79. Ye Q., Vincze A., Horvai G., Leermakers F.A.M., Partial blocking of ion transport at the interface of an ion-selective liquid membrane electrode by neutral surfactants. Experiments and computer simulation. Electrochim. Acta $1998, \quad 44, \quad 125 . \quad$ doi:10.1016/S00134686(98)00160-1

80. Larsen M., The effect of non-ionic surfactants on the potentiometric response of ion selective electrodes. Master Thesis Niels Bohr Institutet 2009.

81. Zhang W., Horan K., Uretsky L., Use of polyoxyalkylene nonionic surfactants with magnesium ion selective electrodes. US Patent, WO 2010/021923 (2010). 